\title{
Astaxanthin as a Peroxisome Proliferator-Activated Receptor (PPAR) Modulator: Its Therapeutic Implications
}

\author{
Chang-Ik Choi \\ College of Pharmacy, Dongguk University-Seoul, Goyang 10326, Korea; cichoi@dongguk.edu; \\ Tel.: +82-31-961-5230
}

Received: 4 April 2019; Accepted: 19 April 2019; Published: 23 April 2019

\begin{abstract}
Peroxisome proliferator-activated receptors (PPARs) are part of the nuclear hormone receptors superfamily that plays a pivotal role in functions such as glucose and lipid homeostasis. Astaxanthin (ASX) is a lipid-soluble xanthophyll carotenoid synthesized by many microorganisms and various types of marine life that is known to possess antioxidant, anti-inflammatory, antidiabetic, anti-atherosclerotic, and anticancer activities. As such, it is a promising nutraceutical resource. ASX-mediated modulation of PPARs and its therapeutic implications in various pathophysiological conditions are described in this review. ASX primarily enhances the action of PPAR $\alpha$ and suppresses that of PPAR $\beta / \delta$ and PPAR $\gamma$, but it has also been confirmed that ASX displays the opposite effects on PPARs, depending on the cell context. Anti-inflammatory effects of ASX are mediated by PPAR $\gamma$ activation, which induces the expression of pro-inflammatory cytokines in macrophages and gastric epithelial cells. The PPAR $\gamma$-agonistic effect of ASX treatment results in the inhibition of cellular growth and apoptosis in tumor cells. Simultaneous and differential regulation of PPAR $\alpha$ and PPAR $\gamma$ activity by ASX has demonstrated a hepatoprotective effect, maintaining hepatic lipid homeostasis and preventing related hepatic problems. Considering additional therapeutic benefits of ASX such as anti-gastric, cardioprotective, immuno-modulatory, neuroprotective, retinoprotective, and osteogenic effects, more studies on the association between ASX-mediated PPAR regulation and its therapeutic outcomes in various pathophysiological conditions are needed to further elucidate the role of ASX as a novel nutraceutical PPAR modulator.
\end{abstract}

Keywords: astaxanthin; peroxisome proliferator-activated receptors (PPARs); anti-inflammation; anticancer; lipid and glucose metabolism; PPAR modulator

\section{Introduction}

Peroxisome proliferator-activated receptors (PPARs) are members of the nuclear hormone receptors superfamily and are ligand-activated transcription factors [1]. They play an important role in the expression of many genes regulating cellular differentiation, the metabolism of glucose and lipids, and carcinogenesis [2-4]. Since the first PPAR was discovered in 1990 [5], three isoforms (PPAR $\alpha, \beta / \delta$, and $\gamma$ ) have been identified in mammalian species [6]. PPAR $\alpha$ is mainly expressed in the liver, kidney, heart, and skeletal muscle and is mainly involved in lipid metabolism and insulin sensitivity $[7,8]$. PPAR $\beta / \delta$ is ubiquitous throughout the human body and is responsible for epithelial cell growth, fatty acid oxidation, and wound healing, [9,10]. PPAR $\gamma$ is the most studied subtype and is found primarily in adipose tissues. In addition to its major role in glucose and lipid homeostasis, PPAR $\gamma$ is also associated with inflammatory responses, cardiovascular diseases, neurogenerative diseases, ocular diseases, and cancer [11]. Since these various physiological functions of PPARs can serve as therapeutic targets for the treatment of chronic diseases, researchers have studied synthetic and 
naturally occurring substances, as well as marine organisms, to identify specific ligands that modulate PPAR activities [12-21].

Astaxanthin (ASX; 3,3'-dihydroxy- $\beta, \beta$-carotene-4, $4^{\prime}$-dione) (Figure 1 ) is a lipid-soluble, red-orange-colored xanthophyll carotenoid synthesized by many microorganisms and various types of marine life [22]. ASX was first identified from Astacus gammarus (European lobster) in 1938 [23] and was initially approved as a food dye for salmon, trout, and shrimp feed in aquaculture industries [24]. Later in 1999, the United States Food and Drug Administration (USFDA) allowed the use of ASX as a dietary supplement [25]. A green microalga, Haematococcus pluvialis, is known to be a major producer of ASX. It accumulates up to $5 \%$ dry weight of ASX during encystment, which includes four progressive cellular morphological phases (Figure 2) [26]. Because synthetic ASX from petrochemicals exhibited inferior effects on human health when compared with natural algal-based ASX [27], many studies have been conducted on maximizing ASX production from H. pluvialis [28-32].

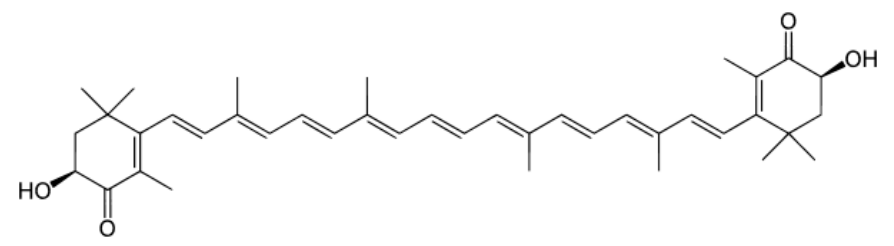

Figure 1. Chemical structure of astaxanthin (ASX).
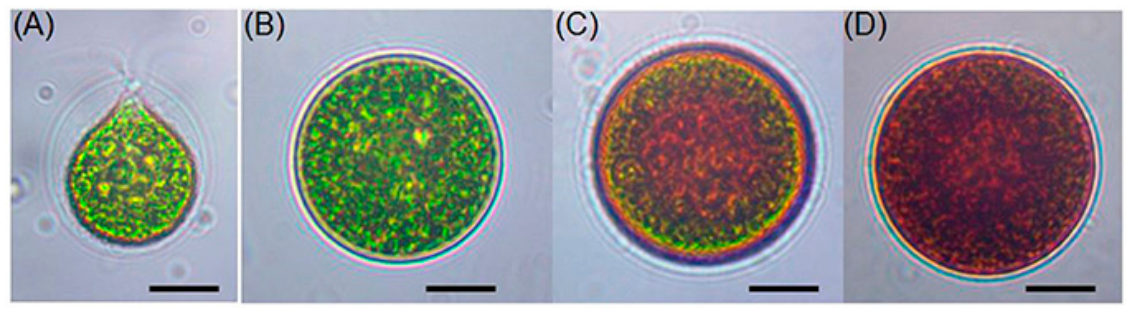

Figure 2. Microscopic appearance in Haematococcus pluvialis encystment. (A) green vegetative motile cell; (B) green vegetative palmella cell; (C) palmella cell accumulating ASX; (D) ASX fully-accumulated red aplanospore cell (from Shah et al. [26] distributed under the terms of the Creative Commons Attribution 4.0 International License (CC BY 4.0)).

Numerous studies have demonstrated various biological properties and mechanisms of action of ASX. It displays antioxidant, anti-inflammatory, antidiabetic, anti-atherosclerotic, and anticancer activities and is a promising nutraceutical resource [33-38]. In this article, ASX-mediated PPAR modulation and its therapeutic implications are extensively reviewed and discussed.

\section{Effects of ASX on PPAR Isoforms}

\subsection{PPAR $\alpha$}

Most studies indicate that ASX acts as an agonist to PPAR $\alpha$ [39-41]. Jia et al. [39] demonstrated that ASX significantly increased PPAR $\alpha$ transactivation efficacy in PPAR $\alpha$-transfected Chinese hamster ovary (CHO-K1) cells; this effect was concentration-dependent. They also showed that ASX exhibits direct binding to human PPAR $\alpha$ ligand binding domain with a $\mathrm{K}_{\mathrm{D}}$ value (concentration at which a compound dissociates from the immobilized protein after the association phase) of $197 \mu \mathrm{M}$. The proportional sigmoidal increase in the time-resolved fluorescence resonance energy transfer (TR-FRET) ratio in agonist assay mode (the half-maximal effective concentration $\left.\left(\mathrm{EC}_{50}\right)=3.9 \mu \mathrm{M}\right)$ suggested that ASX plays a role as a ligand to activate PPAR $\alpha$. Furthermore, ASX significantly induced PPAR $\alpha$ transcription and affected the expression of related target genes in HepG2 human hepatocellular carcinoma cells. In two other in vivo studies that used animals with a high-fat diet, administration of ASX alone [40] or in a combined treatment with flaxseed oil [41] showed a significant and 
dose-dependent increase in hepatic expression of the PPAR $\alpha$ gene and protein. Meanwhile, a recent study [42] reported that ASX is predicted to suppress the expression of PPAR $\alpha$ and its target molecules in the livers of mice with diet-induced nonalcoholic steatohepatitis (NASH).

\section{2. $P P A R \beta / \delta$}

Because early studies have not identified any significant relationship between ASX and PPAR $\beta / \delta$ expression and/or activity [39,43], follow-up studies have not been conducted consistently. The relevant effect of ASX on PPAR $\beta / \delta$ was first confirmed by Kobori et al. [42] when they discovered that ASX significantly decreased mRNA expression of PPAR $\beta / \delta$ and related target genes in NASH mice. Another study by Rundblad et al. [44] also demonstrated that the intake of high-oleic sunflower oil (HOSO) with added ASX downregulates mRNA expression of genes associated with glucose and lipid metabolism, including PPAR $\beta / \delta$, in the peripheral blood mononuclear cells (PBMCs) of healthy volunteers. Similar observations were observed in subjects receiving krill oil containing the same amount of ASX.

\subsection{PPAR $\gamma$}

The physiological role of ASX in PPAR $\gamma$ expression and activity is quite complex. The association between ASX and PPAR $\gamma$ was first described in 2005 [45] when a specific PPAR $\gamma$ antagonist, GW9662, strongly inhibited ASX-induced expression of connexin 43, a protein related to early processes in carcinogenesis [46]. Similar observations were reported in ASX-treated K562 leukemia cells [47] and AGS cells (human gastric epithelial adenocarcinoma cell line) [48]. ASX significantly and dose-dependently induced cellular apoptosis and PPAR $\gamma$ protein expression in K562 cells, and these effects were attenuated by GW9662 [47]. Most recently, ASX was found to increase the expression and DNA-binding activity of PPAR $\gamma$ in Helicobacter pylori-infected AGS cells in a dose-dependent manner. In those same cells, ASX also improved catalase activity, inhibited intracellular and mitochondrial reactive oxygen species (ROS) levels, and diminished the gene expression of inflammatory cytokines that are suppressed by GW9662 co-treatment [48]. Another study by Kim et al. [49] also showed a significant increase in PPAR $\gamma$ mRNA levels along with other osteogenesis- and adipogenesis-related genes in ASX-treated neural stem cells.

In contrast, other studies have suggested that ASX may be a PPAR $\gamma$ antagonist. Jia et al. [39] reported that ASX dose-dependently inhibited PPAR $\gamma$ transactivation with a more than 16-fold higher $\mathrm{K}_{\mathrm{D}}$ value $(11.9 \mu \mathrm{M})$ compared with the value observed in PPAR $\alpha$. In the TR-FRET coactivator antagonist assay mode, the half-maximal inhibitory concentration $\left(\mathrm{IC}_{50}\right)$ value for PPAR $\gamma$ was $607.8 \mu \mathrm{M}$. In addition, the expression of PPAR $\gamma$ and related genes was also significantly decreased by ASX treatment. Her et al. [50] used the ubiquitous transcription factor Yin Yang 1 (YY1)-transgenic zebrafish lines (GY), which are characterized by their induced expression of lipogenic genes, including PPAR $\gamma$, associated with CCAAT-enhancer-binding protein (C/EBP) homologous protein 10 (CHOP-10) downregulation. The authors observed a marked decrease in PPAR $\gamma$ expression with preserved CHOP-10 levels in high-level GY-expressing (GY-H) larvae, which is characteristic of normal zebrafish lines. In an in vivo approach, high-dose ASX $(30 \mu \mathrm{M})$ suppressed PPAR $\gamma$ expression and consequently influenced the mRNA levels of several genes involved in hepatic lipid metabolism in mice fed a high-fat $\operatorname{diet}[40]$.

Considering these conflicting outcomes, Inoue et al. [43] advanced a new theory that ASX acts as a selective PPAR $\gamma$ modulator (SPPARM) depending on the cell context. Among the various xanthophyll carotenoids, ASX only showed dose-proportional binding to PPAR $\gamma$, with less binding affinity and lower maximum activation than the PPAR $\gamma$ full agonist rosiglitazone. Luciferase reporter gene assays using human embryonic kidney 293 (HEK293) cells as well as an evaluation of adipogenesis and target gene expression in 3T3-L1 adipocytes demonstrated that ASX has an antagonistic effect on PPAR $\gamma$. Meanwhile, ASX treatment increased mRNA and/or protein expression of liver X receptor (LXR) and CD36 in a dose-dependent manner. Subsequently, ASX also increased the induction of ATP-binding cassette transporter ABCA1 and ABCG1 in thioglycollate-elicited peritoneal macrophages, which is 
attributable to the action of PPAR $\gamma$ agonists. The authors suggested possible benefits of ASX for the management of various chronic diseases, through the adaptive PPAR $\gamma$-modulating effect.

\section{PPAR-Related Therapeutic Implications of ASX}

The biological and pathophysiological activities of ASX due to its regulation of PPARs are summarized in Table 1.

\subsection{Anti-Inflammatory Effects}

The anti-inflammatory properties of ASX have been described by many previous studies [33,37], and various molecular mechanisms of action have been suggested. These include a blockade of the nuclear factor kappa-light-chain-enhancer of activated B cells (NF-kB) signaling pathway [51-56], inhibition of c-Jun N-terminal kinase (JNK) in the mitogen-activated protein kinase (MAPK) signaling pathway [54,56], prevention of ROS accumulation by nuclear factor E2-related factor 2 (Nrf2) [55], positive modulation of Src homology region 2 domain-containing phosphatase-1 (SHP-1) protein expression [51], suppression of cyclooxygenase-2 (COX-2) and inducible nitric oxide synthase (iNOS) [57], and induction of heme oxygenase-1 (HO-1) [58].

Although more investigations are needed to clarify the association between PPARs and inflammation, it has been reported that PPAR $\gamma$ ligands can regulate inflammatory responses by the transrepression of several signaling pathways (NF- $\mathrm{KB}$, activating protein 1 (AP-1), and signal tranducer and activator of transcription (STAT)-1) [59]. In agreement with this, ASX showed the induction of LXR and CD36 mRNA expression via PPAR $\gamma$ activation in macrophages [43]. In addition to their involvement in cholesterol and lipid metabolism, LXRs also suppress the expression of pro-inflammatory genes such as tumor necrosis factor $\alpha$ (TNF- $\alpha$ ), COX-2, iNOS, and matrix metalloprotease 9 (MMP9) [60]. CD36, a class B transmembrane scavenger receptor, is expressed by multiple cell types including macrophages and plays an important role in the pro-inflammatory and oxidative pathways [61,62]. ASX also exhibited protective effects against $H$. pylori-induced gastric inflammation [48]. H. pylori induces the release and activation of inflammatory cytokines, such as interleukin (IL)-8, via NF-kB activation in gastric mucosa [63-65]. Subsequently, IL-8 stimulates the assembly of neutrophils and ROS generation in the infected lesion [66]. PPAR $\gamma$ activation by ASX treatment improved the activity of antioxidant enzyme catalase (a downstream target gene for PPAR $\gamma$ ), restored ROS overproduction, and inhibited IL-8 expression in H. pylori-infected gastric epithelial cells.

Meanwhile, ASX-mediated reductions in plasma and hepatic TNF- $\alpha$ and IL- 6 expression were reported in an in vivo study [40], which suggests the possible involvement of PPAR $\alpha$ activation, but not of PPAR $\gamma$ activation. 
Table 1. Summary of PPAR-related biological and pathophysiological activities of ASX.

\begin{tabular}{|c|c|c|c|c|}
\hline Biological Activity & Effect on PPARs & Study Model & Study Result(s) & References \\
\hline \multirow{3}{*}{ Anti-inflammatory } & $\operatorname{PPAR} \gamma \uparrow$ & $\begin{array}{l}\text { Thioglycollate-elicited peritoneal } \\
\text { macrophages from C57BL/6J mice }\end{array}$ & Induced mRNA expressions of LXR and CD36 & [43] \\
\hline & $\operatorname{PPAR} \gamma \uparrow$ & $\begin{array}{l}\text { H. pylori-infected AGS human gastric } \\
\text { epithelial cells }\end{array}$ & $\begin{array}{l}\text { Inhibition of } H \text {. pylori-induced increase in intracellular and mitochondrial ROS levels } \\
\text { and IL-8 gene expression }\end{array}$ & [48] \\
\hline & $\operatorname{PPAR} \alpha \uparrow$ & High-fat diet-fed C57BL/6J male mice & Reduced mRNA expression and plasma and liver levels of TNF- $\alpha$ and IL- 6 & [40] \\
\hline \multirow[t]{2}{*}{ Anticancer } & $\operatorname{PPAR} \gamma \uparrow$ & $\begin{array}{l}\mathrm{C} 3 \mathrm{H} / 10 \mathrm{~T} 1 / 2 \text { mouse embryonic } \\
\text { fibroblast cells }\end{array}$ & Induction of connexin 43 expression & [45] \\
\hline & $\operatorname{PPAR} \gamma \uparrow$ & K562 leukemia cells & Cellular growth inhibition, cell cycle arrest and induction of apoptosis & [47] \\
\hline \multirow{8}{*}{$\begin{array}{l}\text { Lipid and glucose } \\
\text { homeostasis }\end{array}$} & PPAR $\alpha \uparrow$, PPAR $\gamma \downarrow$ & $\begin{array}{l}\text { Lipid-loaded HepG2 human } \\
\text { hepatocellular carcinoma cells }\end{array}$ & $\begin{array}{l}\text { Reduced cellular cholesterol and triglyceride contents; changes in target gene } \\
\text { expressions for PPAR } \alpha \text { and PPAR } \gamma \text { involved in lipid and glucose metabolism pathways }\end{array}$ & [39] \\
\hline & $\operatorname{PPAR} \alpha \uparrow, \operatorname{PPAR} \gamma \downarrow$ & High-fat diet-fed C57BL/6J male mice & $\begin{array}{l}\text { Altered expressions in several PPAR } \alpha \text { and PPAR } \gamma \text { target genes; reduced hepatic } \\
\text { steatosis }\end{array}$ & [40] \\
\hline & $\operatorname{PPAR} \alpha \uparrow$ & $\begin{array}{l}\text { High-fat diet-fed Sprague-Dawley } \\
\text { rats }\end{array}$ & $\begin{array}{l}\text { Increased mRNA expressions in CPT1 and ACOX; decreased mRNA expressions in } \\
\text { SREBP1, HMGCR, FAS, and ACC; reduced hepatic steatosis and hepatic triglyceride } \\
\text { and total cholesterol levels }\end{array}$ & [41] \\
\hline & $\operatorname{PPAR} \gamma \uparrow$ & YY1-transgenic zebrafish & $\begin{array}{l}\text { Yellow and greasy appearance and marked lipid accumulation in the hepatocytes; } \\
\text { increased mRNA expression of genes responsible for the fatty acid synthesis, transport } \\
\text { and binding, lipid storage, and hepatic lipogenesis; upregulation of C/EBP } \alpha \text { and PPAR } \gamma \\
\text { target genes; gross liver hypoplasia and related lipotoxicity }\end{array}$ & [50] \\
\hline & PPAR $\alpha \downarrow$, PPAR $\beta / \delta \downarrow$ & $\begin{array}{l}\text { C57BL/6J mice with high-cholesterol, } \\
\text { high-cholate, and high-fat } \\
\text { diet-induced NASH }\end{array}$ & Changes in PPAR target genes (inhibition of PNPLA2; activation of PML) & [42] \\
\hline & PPAR $\gamma \downarrow$ & 3T3-L1 adipocytes & $\begin{array}{l}\text { Inhibition of rosiglitazone-induced lipid accumulation; reduced aP2, FABP, and LPL } \\
\text { mRNA levels }\end{array}$ & [43] \\
\hline & $\operatorname{PPAR} \gamma \uparrow$ & Mouse neural stem cells & Increased lipid accumulation; overexpression of adipogenic genes & [49] \\
\hline & PPAR $\beta / \delta \downarrow$ & PBMCs from healthy volunteers & $\begin{array}{l}\text { Downregulation of genes involved in lipid and glucose metabolism (including } \\
\text { PPAR } \beta / \delta \text { ) }\end{array}$ & [44] \\
\hline
\end{tabular}

ACC, acetyl-CoA carboxylase; ACOX, acyl-CoA oxidase; aP2, adipocyte protein 2; ASX, astaxanthin; CPT1, carnitine palmitoyltransferase 1; FABP, fatty acid binding protein; FAS, fatty acid synthase; HMGCR, 3-hydroxy-3-methylglutaryl-CoA reductase; IL, interleukin; LPL, lipoprotein lipase; LXR, liver X receptor; NASH, nonalcoholic steatohepatitis; PBMC, peripheral blood mononuclear cell; PML, promyelocytic leukemia protein; PNPLA2, patatin-like phospholipase domain containing 2; PPAR, peroxisome proliferator-activated receptor; ROS, reactive oxygen species; SREBP1, sterol regulatory element binding protein 1; TNF- $\alpha$, tumor necrosis factor $\alpha$; YY1, Yin Yang 1 transcription factor 


\subsection{Anticancer Effects}

ASX has demonstrated anticancer activity through multiple mechanisms including cell growth inhibition, apoptosis induction, and interference of cell cycle progression [34]. Suggested molecular targets for ASX-induced cancer prevention and treatment include NF- $\mathrm{kB}$, Janus kinase (JAK)/STAT-3, phosphatidylinositide 3-kinase/protein kinase B (PI3K/Akt), MAPK, Nrf2, and PPAR $\gamma$ [34]. Although some PPAR $\gamma$ agonists have shown pro-tumorigenic activities [67-70], PPAR $\gamma$ activation is also considered a promising therapeutic target for novel anticancer agents. This is based on its suppression of cellular growth and proliferation as well as its promotion of terminal differentiation and apoptosis [71-73].

As mentioned previously, a specific PPAR $\gamma$ antagonist (GW9662) suppressed ASX-mediated induction of the connexin 43 gene in mouse embryonic fibroblasts $(\mathrm{C} 3 \mathrm{H} / 10 \mathrm{~T} 1 / 2)$ [45]. This result implies that cancer-preventive upregulation of connexin 43 is associated with ASX and its ability to activate PPAR $\gamma$. Zhang et al. [47] also demonstrated that ASX, in a time- and/or dose-dependent manner, inhibited cell growth, decreased cell viability, and induced cell cycle arrest and apoptosis in K562 leukemia cells, which are partly attenuated through the preincubation of GW9662.

In addition to PPAR $\gamma$, the roles of other PPAR subtypes in carcinogenesis and chemoprevention have been demonstrated [4]. For example, PPAR $\alpha$-dependent hepatocarcinogenesis has been reported in chronic rodent models [74], and PPAR $\alpha$ agonists have been found to attenuate cell growth and angiogenesis in various tumor strains including A459 human non-small cell lung cancer, B16-F10 murine melanoma, Lewis lung carcinoma, U87 human glioblastoma, and HT-1080 human fibrosarcoma [75,76]. There is limited proof that downregulation of PPAR $\beta / \delta$ by several antagonists can inhibit tumorigenesis; thus, there are still conflicting opinions on the relationship between PPAR $\beta / \delta$ and cancer development, treatment, and prevention [77,78]. Further comprehensive research on ASX-mediated PPAR $\alpha$ or $\mathrm{PPAR} \beta / \delta$ modulation and therapeutic impacts on cancer progression are necessary to elucidate its possible anticancer properties.

\subsection{Effects on Lipid and Glucose Metabolism}

All PPAR subtypes are involved in lipid and carbohydrate metabolism as well as the management of metabolic syndrome and related disorders such as obesity, type 2 diabetes, atherosclerosis, and non-alcoholic fatty liver disease (NAFLD) [11,79]. Most studies have demonstrated that the physiological role of ASX is mainly focused on hepatic lipid and glucose metabolism via the modulation of PPAR $\alpha$ and/or PPAR $\gamma$.

With its dual role as a PPAR $\alpha$ agonist and PPAR $\gamma$ antagonist, Jia et al. [39] showed that ASX treatment decreases intracellular cholesterol and triglyceride contents in lipid-loaded HepG2 cells. Furthermore, ASX altered the expression of genes that target PPAR $\alpha$ and PPAR $\gamma$. It increased the expression of sterol carrier protein 2 (SCP2), acyl-CoA dehydrogenase very long chain (ACADVL), acyl-CoA dehydrogenase medium chain (ACADM), enoyl-CoA hydratase and 3-hydroxyacyl CoA dehydroganase (EHHADH), and sterol 27-hydroxylase (CYP27A1). It also decreased the expression of carnitine palmitoyltransferase (CPT) 2 and aconitase 1 (ACO1), which are involved in various lipid and glucose metabolism pathways. The results from hepatic transcriptome profile analyses were comparable to those of the commonly used hypolipidemic agents fenofibrate and lovastatin, suggesting a preventive role for ASX in metabolic disorders associated with hepatic hyperlipidemia like NAFLD or $\mathrm{NASH}$. The in vivo effects of ASX on lipid metabolism were also assessed by the same laboratory [40], and they observed significantly increased PPAR $\alpha$ and reduced PPAR $\gamma$ gene and protein expression in high-fat diet-fed mice with a co-treatment of ASX. Several PPAR $\alpha$ and PPAR $\gamma$-related target genes that play key roles in fatty acid uptake (caveolin-1), fatty acid $\beta$-oxidation (CPT1 and acyl-CoA oxidase (ACOX) 1), triglyceride hydrolysis (lipoprotein lipase (LPL)), and mitochondrial thermogenesis (uncoupling protein 2 (UCP2)) were also upregulated by ASX administration. The expression of lipogenic genes regulated by PPAR $\alpha$ such as sterol regulatory element binding protein (SREBP) 1c, fatty acid synthase (FAS), and acetyl-CoA carboxylate 1 (ACC1) were not affected by ASX; however, 
$\mathrm{LXR} \alpha$, which may contribute to an increase in plasma high-density lipoprotein (HDL) cholesterol levels, was affected by ASX. In addition, ASX reduced hepatic steatosis through PPAR-mediated inhibition of the Akt-mTOR axis and activation of autophagy pathways. The authors concluded that ASX treatment ameliorates high-fat diet-induced hepatic lipid accumulation and hepatic steatosis in mice via differential regulatory actions involving PPAR $\alpha$ and PPAR $\gamma$. Another in vivo study by Xu et al. [41] investigated the effect of an ASX and flaxseed oil combination on hepatic lipid accumulation and oxidative stress. The combination resulted in the upregulation of PPAR $\alpha$ protein expression and the increased mRNA expression of CPT1 and ACOX in high-fat diet-fed male rats. It also caused the downregulation of 3-hydroxy-3-methylglutaryl-CoA reductase (HMGCR) and SREBP1 proteins and decreased mRNA levels for FAS and ACC. These results could support the hepatoprotective properties of ASX and flaxseed oil confirmed by the reversal of hepatic steatosis, decrease in hepatic triglyceride and total cholesterol levels, and enhancement in liver antioxidant capacity.

In contrast, increased PPAR $\gamma$ expression was associated with the development of hepatic steatosis and lipotoxicity in GY zebrafish [50]. Overexpression of YY1 transcription factor caused yellow and greasy liver appearance as well as marked lipid accumulation in hepatocytes compared to control zebrafish lines. The mRNA expression levels were also increased in genes responsible for fatty acid synthesis, transport and binding, lipid storage, and hepatic lipogenesis. YY1-mediated suppression of CHOP-10 expression caused upregulation of C/EBP $\alpha$ and PPAR $\gamma$ and related target genes such as adipocyte protein 2 (aP2), caveolin-1, adiponectin, adipsin, and fat-specific gene 27 (FSP27). As a result of progressive hepatic steatosis, more than $90 \%$ of adult GY fish exhibited liver abnormalities (i.e., gross liver hypoplasia) and related lipotoxicity, which included increased lipid peroxidation, ROS generation, gene expression involving lipid $\beta$-oxidation, and lipo-apoptosis.

Kobori et al. [42] presented different results from those of previous studies and in which ASX was predicted to decrease the actions of PPAR $\alpha$ and PPAR $\beta / \delta$ and reduce the mRNA levels of related genes in mice with diet-induced NASH. In addition, the expressions of PPAR target molecules such as patatin-like phospholipase domain containing 2 (PNPLA2) and promyelocytic leukemia protein (PML) were also affected by ASX. The authors suggested that the inhibitory effect of ASX on hepatic gene expression, which leads to reduced mitochondrial fatty acid oxidation, is attributable to the suppression of PPAR $\alpha$ activity. Thus, further scientific studies are required to elucidate the molecular actions of ASX on PPAR function.

Several studies have also shown the effect of ASX on lipid and/or glucose control using other cellular resources. ASX completely inhibited rosiglitazone-induced lipid accumulation and reduced the mRNA expression of PPAR $\gamma$ target genes (aP2, fatty acid-binding protein, and LPL) in 3T3-L1 adipocyte [43]. In contrast, enhanced adipogenic differentiation and significant overexpression of PPAR $\gamma$ and other adipogenic genes were observed in ASX-treated neural stem cells [49]. More recently, Rundblad et al. [44] reported that the intake of ASX-added HOSO supplementation downregulates the expression of PPAR $\beta / \delta$, as well as other genes affecting lipid and glucose metabolism, in PBMCs from healthy subjects.

\section{Conclusions and Future Prospects}

ASX exhibits significant anti-inflammatory and anticancer properties, and it helps regulate lipid and glucose metabolism based on its differential modulation of PPARs depending on the type of cells. Like other previously reported molecular mechanisms, ASX-mediated PPAR $\gamma$ activation induces the expression of many pro-inflammatory molecules in macrophages and gastric epithelial cells. Despite the conflicting views regarding the effect of PPARs on cancer, the agonistic effect on PPAR $\gamma$ by ASX treatment leads to the inhibition of growth and cell cycle as well as an induction of apoptosis against several tumor cells. The effects of ASX on lipid and glucose metabolism associated with PPAR modulation are somewhat complicated. Simultaneous PPAR $\alpha$ activation and PPAR $\gamma$ suppression play a major role in hepatic lipid homeostasis as well as NAFLD and NASH, but the overexpression of 
PPAR $\gamma$ causes excessive hepatic lipid accumulation. Changes in PPAR expression also affect lipid and glucose metabolism in adipocytes and PBMCs.

PPARs are distributed ubiquitously and are involved in maintaining homeostasis and controlling diseases in human body. A variety of PPAR ligands have been discovered, and though they are known to play a role in metabolic disorders such as type 2 diabetes and dyslipidemia, research on their new therapeutic potential is ongoing because of their vast influence on human health. For example, PPAR $\gamma$ has been found to provide additional benefits for cardiovascular homeostasis and related functional problems including atherosclerosis, restenosis, and hypertension [80]. PPAR $\gamma$ also plays a beneficial role in neurodegenerative disorders such as Parkinsonism, amyotrophic lateral sclerosis, Alzheimer's disease and brain injury, and ocular diseases $[6,81,82]$. Furthermore, PPAR $\beta / \delta$ has been implicated in cardiac function, epidermal biology, neuroprotection, and gastrointestinal tract functions [83-86]. Spurred by these findings, numerous clinical trials are underway, which are exploring PPAR-based therapies for the treatment of many diseases [87].

Considering that ASX has a wide range of biological activities not covered in detail in this review, including anti-gastric, cardioprotective, immuno-modulatory, neuroprotective, retinoprotective, and osteogenic effects [33,37], further comprehensive studies of ASX-mediated influence on PPAR activity and its therapeutic outcomes in various pathophysiological conditions are necessary to clarify the role of ASX as a novel nutraceutical PPAR modulator.

Funding: This work was supported by the Basic Science Research Program through the National Research Foundation of Korea (NRF), funded by the Ministry of Education (No. 2016R1D1A1B03933963).

Conflicts of Interest: The author declares no conflict of interest.

\section{References}

1. Michalik, L.; Auwerx, J.; Berger, J.P.; Chatterjee, V.K.; Glass, C.K.; Gonzalez, F.J.; Grimaldi, P.A.; Kadowaki, T.; Lazar, M.A.; O'Rahilly, S.; et al. International Union of Pharmacology. LXI. Peroxisome proliferator-activated receptors. Pharmacol. Rev. 2006, 58, 726-741. [CrossRef]

2. Lee, C.H.; Olson, P.; Evans, R.M. Minireview: Lipid metabolism, metabolic diseases, and peroxisome proliferator-activated receptors. Endocrinology 2003, 144, 2201-2207. [CrossRef] [PubMed]

3. Marx, N.; Duez, H.; Fruchart, J.C.; Staels, B. Peroxisome proliferator-activated receptors and atherogenesis: regulators of gene expression in vascular cells. Circ. Res. 2004, 94, 1168-1178. [CrossRef] [PubMed]

4. Peters, J.M.; Shah, Y.M.; Gonzalez, F.J. The role of peroxisome proliferator-activated receptors in carcinogenesis and chemoprevention. Nat. Rev. Cancer 2012, 12, 181-195. [CrossRef] [PubMed]

5. Issemann, I.; Green, S. Activation of a member of the steroid hormone receptor superfamily by peroxisome proliferators. Nature 1990, 347, 645-650. [CrossRef]

6. Tyagi, S.; Gupta, P.; Saini, A.S.; Kaushal, C.; Sharma, S. The peroxisome proliferator-activated receptor: A family of nuclear receptors role in various disease. J. Adv. Pharm. Technol. Res. 2011, 2, 236-240. [CrossRef]

7. Pyper, S.R.; Viswakarma, N.; Yu, S.; Reddy, J.K. PPAR $\alpha$ : energy combustion, hypolipidemia, inflammation and cancer. Nucl. Recept. Signal. 2010, 8, e002. [CrossRef] [PubMed]

8. Guerre-Millo, M.; Gervois, P.; Raspé, E.; Madsen, L.; Poulain, P.; Derudas, B.; Herbert, J.M.; Winegar, D.A.; Willson, T.M.; Fruchart, J.C.; et al. Peroxisome proliferator-activated receptor alpha activators improve insulin sensitivity and reduce adiposity. J. Biol. Chem. 2000, 275, 16638-16642. [CrossRef] [PubMed]

9. Burdick, A.D.; Kim, D.J.; Peraza, M.A.; Gonzalez, F.J.; Peters, J.M. The role of peroxisome proliferator-activated receptor-beta/delta in epithelial cell growth and differentiation. Cell. Signal. 2006, 18, 9-20. [CrossRef]

10. Hamblin, M.; Chang, L.; Fan, Y.; Zhang, J.; Chen, Y.E. PPARs and the cardiovascular system. Antioxid. Redox Signal. 2009, 11, 1415-1452. [CrossRef] [PubMed]

11. Mirza, A.Z.; Althagafi, I.I.; Shamshad, H. Role of PPAR receptor in different diseases and their ligands: Physiological importance and clinical implications. Eur. J. Med. Chem. 2019, 166, 502-513. [CrossRef] [PubMed]

12. Grygiel-Górniak, B. Peroxisome proliferator-activated receptors and their ligands: nutritional and clinical implications-A review. Nutr. J. 2014, 13, 17. [CrossRef] [PubMed] 
13. Tan, C.K.; Zhuang, Y.; Wahli, W. Synthetic and natural Peroxisome Proliferator-Activated Receptor (PPAR) agonists as candidates for the therapy of the metabolic syndrome. Expert Opin. Ther. Targets 2017, 21, 333-348. [CrossRef] [PubMed]

14. Su, M.; Cao, J.; Huang, J.; Liu, S.; Im, D.S.; Yoo, J.W.; Jung, J.H. The In Vitro and In Vivo Anti-Inflammatory Effects of a Phthalimide PPAR- $\gamma$ Agonist. Mar. Drugs 2017, 15, 7. [CrossRef]

15. Moldes-Anaya, A.; Sæther, T.; Uhlig, S.; Nebb, H.I.; Larsen, T.; Eilertsen, H.C.; Paulsen, S.M. Two Isomeric C16 Oxo-Fatty Acids from the Diatom Chaetoceros karianus Show Dual Agonist Activity towards Human Peroxisome Proliferator-Activated Receptors (PPARs) $\alpha / \gamma$. Mar. Drugs 2017, 15, 148. [CrossRef]

16. Huang, F.; Wang, J.; Yu, F.; Tang, Y.; Ding, G.; Yang, Z.; Sun, Y. Protective Effect of Meretrix meretrix Oligopeptides on High-Fat-Diet-Induced Non-Alcoholic Fatty Liver Disease in Mice. Mar. Drugs 2018, 16, 39. [CrossRef]

17. Oliveira, R.M.; Câmara, R.B.G.; Monte, J.F.S.; Viana, R.L.S.; Melo, K.R.T.; Queiroz, M.F.; Filgueira, L.G.A.; Oyama, L.M.; Rocha, H.A.O. Commercial Fucoidans from Fucus vesiculosus Can Be Grouped into Antiadipogenic and Adipogenic Agents. Mar. Drugs 2018, 16, 193. [CrossRef] [PubMed]

18. Weng, J.R.; Chiu, C.F.; Hu, J.L.; Feng, C.H.; Huang, C.Y.; Bai, L.Y.; Sheu, J.H. A Sterol from Soft Coral Induces Apoptosis and Autophagy in MCF-7 Breast Cancer Cells. Mar. Drugs 2018, 16, 238. [CrossRef]

19. Woo, M.; Song, Y.O.; Kang, K.H.; Noh, J.S. Anti-Obesity Effects of Collagen Peptide Derived from Skate (Raja kenojei) Skin Through Regulation of Lipid Metabolism. Mar. Drugs 2018, 16, 306. [CrossRef]

20. Vitale, R.M.; D’Aniello, E.; Gorbi, S.; Martella, A.; Silvestri, C.; Giuliani, M.E.; Fellous, T.; Gentile, A.; Carbone, M.; Cutignano, A.; et al. Fishing for Targets of Alien Metabolites: A Novel Peroxisome Proliferator-Activated Receptor (PPAR) Agonist from a Marine Pest. Mar. Drugs 2018, 16, 431. [CrossRef]

21. Bai, Y.; Zheng, J.; Yuan, X.; Jiao, S.; Feng, C.; Du, Y.; Liu, H.; Zheng, L. Chitosan Oligosaccharides Improve Glucolipid Metabolism Disorder in Liver by Suppression of Obesity-Related Inflammation and Restoration of Peroxisome Proliferator-Activated Receptor Gamma (PPAR $\gamma$ ). Mar. Drugs 2018, 16, 455. [CrossRef] [PubMed]

22. Higuera-Ciapara, I.; Felix-Valenzuela, L.; Goycoolea, F.M. Astaxanthin: A review of its chemistry and applications. Crit. Rev. Food Sci. Nutr. 2006, 46, 185-196. [CrossRef]

23. Kuhn, R.; Sörensen, N.A. Über Astaxanthin und Ovoverdin. Eur. J. Inorg. Chem. 1938, 71, 1879-1888. [CrossRef]

24. Roche, F. Astaxanthin: Human food safety summary. In Astaxanthin As a Pigmenter in Salmon Feed, Color Additive Petition $7 C 02$ 1 1, United States Food and Drug Administration; Hoffman-La Roche Ltd.: Basel, Switzerland, 1987; p. 43.

25. Guerin, M.; Huntley, M.E.; Olaizola, M. Haematococcus astaxanthin: Applications for human health and nutrition. Trends Biotechnol. 2003, 21, 210-216. [CrossRef]

26. Shah, M.M.; Liang, Y.; Cheng, J.J.; Daroch, M. Astaxanthin-Producing Green Microalga Haematococcus pluvialis: From Single Cell to High Value Commercial Products. Front. Plant Sci. 2016, 7, 531. [CrossRef] [PubMed]

27. Capelli, B.; Bagchi, D.; Cysewski, G.R. Synthetic astaxanthin is significantly inferior to algal-based astaxanthin as an antioxidant and may not be suitable as a human nutraceutical supplement. Nutrafoods 2013, 12, 145-152. [CrossRef]

28. Solovchenko, A.E. Recent breakthroughs in the biology of astaxanthin accumulation by microalgal cell. Photosynth. Res. 2015, 125, 437-449. [CrossRef] [PubMed]

29. Sanzo, G.D.; Mehariya, S.; Martino, M.; Larocca, V.; Casella, P.; Chianese, S.; Musmarra, D.; Balducchi, R.; Molino, A. Supercritical Carbon Dioxide Extraction of Astaxanthin, Lutein, and Fatty Acids from Haematococcus pluvialis Microalgae. Mar. Drugs 2018, 16, 334. [CrossRef] [PubMed]

30. Molino, A.; Mehariya, S.; Iovine, A.; Larocca, V.; Di Sanzo, G.; Martino, M.; Casella, P.; Chianese, S.; Musmarra, D. Extraction of Astaxanthin and Lutein from Microalga Haematococcus pluvialis in the Red Phase Using CO2 Supercritical Fluid Extraction Technology with Ethanol as Co-Solvent. Mar. Drugs 2018, 16, 432. [CrossRef] [PubMed]

31. Li, F.; Cai, M.; Lin, M.; Huang, X.; Wang, J.; Ke, H.; Zheng, X.; Chen, D.; Wang, C.; Wu, S.; An, Y. Differences between Motile and Nonmotile Cells of Haematococcus pluvialis in the Production of Astaxanthin at Different Light Intensities. Mar. Drugs 2019, 17, 39. [CrossRef] 
32. Hwang, S.W.; Choi, H.I.; Sim, S.J. Acidic cultivation of Haematococcus pluvialis for improved astaxanthin production in the presence of a lethal fungus. Bioresour. Technol. 2019, 278, 138-144. [CrossRef] [PubMed]

33. Ambati, R.R.; Phang, S.M.; Ravi, S.; Aswathanarayana, R.G. Astaxanthin: Sources, extraction, stability, biological activities and its commercial applications-A review. Mar. Drugs 2014, 12, 128-152. [CrossRef] [PubMed]

34. Zhang, L.; Wang, H. Multiple Mechanisms of Anti-Cancer Effects Exerted by Astaxanthin. Mar. Drugs 2015, 13, 4310-4330. [CrossRef] [PubMed]

35. Wu, H.; Niu, H.; Shao, A.; Wu, C.; Dixon, B.J.; Zhang, J.; Yang, S.; Wang, Y. Astaxanthin as a Potential Neuroprotective Agent for Neurological Diseases. Mar. Drugs 2015, 13, 5750-5766. [CrossRef] [PubMed]

36. Kishimoto, Y.; Yoshida, H.; Kondo, K. Potential Anti-Atherosclerotic Properties of Astaxanthin. Mar. Drugs 2016, 14, 35. [CrossRef]

37. Fakhri, S.; Abbaszadeh, F.; Dargahi, L.; Jorjani, M. Astaxanthin: A mechanistic review on its biological activities and health benefits. Pharmacol. Res. 2018, 136, 1-20. [CrossRef] [PubMed]

38. Galasso, C.; Orefice, I.; Pellone, P.; Cirino, P.; Miele, R.; Ianora, A.; Brunet, C.; Sansone, C. On the Neuroprotective Role of Astaxanthin: New Perspectives? Mar. Drugs 2018, 16, 247. [CrossRef] [PubMed]

39. Jia, Y.; Kim, J.Y.; Jun, H.J.; Kim, S.J.; Lee, J.H.; Hoang, M.H.; Hwang, K.Y.; Um, S.J.; Chang, H.I.; Lee, S.J. The natural carotenoid astaxanthin, a PPAR- $\alpha$ agonist and PPAR- $\gamma$ antagonist, reduces hepatic lipid accumulation by rewiring the transcriptome in lipid-loaded hepatocytes. Mol. Nutr. Food Res. 2012, 56, 878-888. [CrossRef]

40. Jia, Y.; Wu, C.; Kim, J.; Kim, B.; Lee, S.J. Astaxanthin reduces hepatic lipid accumulations in high-fat-fed C57BL/6J mice via activation of peroxisome proliferator-activated receptor (PPAR) alpha and inhibition of PPAR gamma and Akt. J. Nutr. Biochem. 2016, 28, 9-18. [CrossRef]

41. Xu, J.; Rong, S.; Gao, H.; Chen, C.; Yang, W.; Deng, Q.; Huang, Q.; Xiao, L.; Huang, F. A Combination of Flaxseed Oil and Astaxanthin Improves Hepatic Lipid Accumulation and Reduces Oxidative Stress in High Fat-Diet Fed Rats. Nutrients 2017, 9, 271. [CrossRef]

42. Kobori, M.; Takahashi, Y.; Sakurai, M.; Ni, Y.; Chen, G.; Nagashimada, M.; Kaneko, S.; Ota, T. Hepatic Transcriptome Profiles of Mice with Diet-Induced Nonalcoholic Steatohepatitis Treated with Astaxanthin and Vitamin E. Int. J. Mol. Sci. 2017, 18, 593. [CrossRef]

43. Inoue, M.; Tanabe, H.; Matsumoto, A.; Takagi, M.; Umegaki, K.; Amagaya, S.; Takahashi, J. Astaxanthin functions differently as a selective peroxisome proliferator-activated receptor $\gamma$ modulator in adipocytes and macrophages. Biochem. Pharmacol. 2012, 84, 692-700. [CrossRef] [PubMed]

44. Rundblad, A.; Holven, K.B.; Bruheim, I.; Myhrstad, M.C.; Ulven, S.M. Effects of fish and krill oil on gene expression in peripheral blood mononuclear cells and circulating markers of inflammation: A randomized controlled trial. J. Nutr. Sci. 2018, 7, e10. [CrossRef]

45. Vine, A.L.; Bertram, J.S. Upregulation of connexin 43 by retinoids but not by non-provitamin A carotenoids requires RARs. Nutr. Cancer 2005, 52, 105-113. [CrossRef]

46. King, T.J.; Fukushima, L.H.; Hieber, A.D.; Shimabukuro, K.A.; Sakr, W.A.; Bertram, J.S. Reduced levels of connexin43 in cervical dysplasia: inducible expression in a cervical carcinoma cell line decreases neoplastic potential with implications for tumor progression. Carcinogenesis 2000, 21, 1097-1109. [CrossRef] [PubMed]

47. Zhang, X.; Zhao, W.; Hu, L.; Zhao, L.; Huang, J. Carotenoids inhibit proliferation and regulate expression of peroxisome proliferators-activated receptor gamma (PPAR $\gamma)$ in K562 cancer cells. Arch. Biochem. Biophys. 2011, 512, 96-106. [CrossRef]

48. Kim, S.H.; Lim, J.W.; Kim, H. Astaxanthin Inhibits Mitochondrial Dysfunction and Interleukin-8 Expression in Helicobacter pylori-Infected Gastric Epithelial Cells. Nutrients 2018, 10, 1320. [CrossRef]

49. Kim, J.H.; Nam, S.W.; Kim, B.W.; Kim, W.J.; Choi, Y.H. Astaxanthin improves the proliferative capacity as well as the osteogenic and adipogenic differentiation potential in neural stem cells. Food Chem. Toxicol. 2010, 48, 1741-1745. [CrossRef] [PubMed]

50. Her, G.M.; Pai, W.Y.; Lai, C.Y.; Hsieh, Y.W.; Pang, H.W. Ubiquitous transcription factor YY1 promotes zebrafish liver steatosis and lipotoxicity by inhibiting CHOP-10 expression. Biochim. Biophys. Acta 2013, 1831, 1037-1051. [CrossRef] [PubMed]

51. Speranza, L.; Pesce, M.; Patruno, A.; Franceschelli, S.; de Lutiis, M.A.; Grilli, A.; Felaco, M. Astaxanthin treatment reduced oxidative induced pro-inflammatory cytokines secretion in U937: SHP-1 as a novel biological target. Mar. Drugs 2012, 10, 890-899. [CrossRef] 
52. Bhuvaneswari, S.; Yogalakshmi, B.; Sreeja, S.; Anuradha, C.V. Astaxanthin reduces hepatic endoplasmic reticulum stress and nuclear factor- $\mathrm{kB}$-mediated inflammation in high fructose and high fat diet-fed mice. Cell Stress Chaperones 2014, 19, 183-191. [CrossRef] [PubMed]

53. Suzuki, Y.; Ohgami, K.; Shiratori, K.; Jin, X.H.; Ilieva, I.; Koyama, Y.; Yazawa, K.; Yoshida, K.; Kase, S.; Ohno, S. Suppressive effects of astaxanthin against rat endotoxin-induced uveitis by inhibiting the NF- $\mathrm{kB}$ signaling pathway. Exp. Eye Res. 2016, 82, 275-281. [CrossRef]

54. Wen, X.; Xiao, L.; Zhong, Z.; Wang, L.; Li, Z.; Pan, X.; Liu, Z. Astaxanthin acts via LRP-1 to inhibit inflammation and reverse lipopolysaccharide-induced M1/M2 polarization of microglial cells. Oncotarget 2017, 8, 69370-69385. [CrossRef]

55. Farruggia, C.; Kim, M.B.; Bae, M.; Lee, Y.; Pham, T.X.; Yang, Y.; Han, M.J.; Park, Y.K.; Lee, J.Y. Astaxanthin exerts anti-inflammatory and antioxidant effects in macrophages in NRF2-dependent and independent manners. J. Nutr. Biochem. 2018, 62, 202-209. [CrossRef]

56. Li, M.Y.; Sun, L.; Niu, X.T.; Chen, X.M.; Tian, J.X.; Kong, Y.D.; Wang, G.Q. Astaxanthin protects lipopolysaccharide-induced inflammatory response in Channa argus through inhibiting NF- $\mathrm{B}$ and MAPKs signaling pathways. Fish Shellfish Immunol. 2019, 86, 280-286. [CrossRef]

57. Choi, S.K.; Park, Y.S.; Choi, D.K.; Chang, H.I. Effects of astaxanthin on the production of NO and the expression of COX-2 and iNOS in LPS-stimulated BV2 microglial cells. J. Microbiol. Biotechnol. 2008, 18, 1990-1996. [PubMed]

58. Nian, L.; Weidong, Z.; Shujuan, L.; Jun, C.; Minlian, P.; Zhiguang, L. Astaxanthin suppresses cigarette smoke and lipopolysaccharide-induced airway inflammation through induction of heme oxygenase-1. Cell. Mol. Biol. (Noisy-le-grand) 2019, 65, 94-99. [CrossRef]

59. Glass, C.K.; Saijo, K. Nuclear receptor transrepression pathways that regulate inflammation in macrophages and T cells. Nat. Rev. Immunol. 2010, 10, 365-376. [CrossRef] [PubMed]

60. Schulman, G. Liver X receptors link lipid metabolism and inflammation. FEBS. Lett. 2017, 591, $2978-2991$. [CrossRef]

61. Okamura, D.M.; Pennathur, S.; Pasichnyk, K.; López-Guisa, J.M.; Collins, S.; Febbraio, M.; Heinecke, J.; Eddy, A.A. CD36 regulates oxidative stress and inflammation in hypercholesterolemic CKD. J. Am. Soc. Nephrol. 2009, 20, 495-505. [CrossRef]

62. Woo, M.S.; Yang, J.; Beltran, C.; Cho, S. Cell-surface CD36 in monocyte/macrophage contributes to phagocytosis during the resolution phase of ischemic stroke in mice. J. Biol. Chem. 2016, 291, 23654-23661. [CrossRef] [PubMed]

63. Fan, X.G.; Chua, A.; Fan, X.J.; Keeling, P.W. Increased gastric production of interleukin-8 and tumour necrosis factor in patients with Helicobacter pylori infection. J. Clin. Pathol. 1995, 48, 133-136. [CrossRef]

64. Keates, S.; Hitti, Y.S.; Upton, M.; Kelly, C.P. Helicobacter pylori infection activates NF-kappa B in gastric epithelial cells. Gastroenterology 1997, 113, 1099-1109. [CrossRef]

65. Seo, J.H.; Lim, J.W.; Kim, H.; Kim, K.H. Helicobacter pylori in a Korean isolate activates mitogen-activated protein kinases, AP-1, and NF-KB and induces chemokine expression in gastric epithelial AGS cells. Lab. Investig. 2004, 84, 49-62. [CrossRef] [PubMed]

66. Crabtree, J.E.; Farmery, S.M. Helicobacter pylori and gastric mucosal cytokines: Evidence that CagA-positive strains are more virulent. Lab. Investig. 1995, 73, 742-745. [PubMed]

67. Pino, M.V.; Kelley, M.F.; Jayyosi, Z. Promotion of colon tumors in C57BL/6J-APC(min)/+ mice by thiazolidinedione PPAR $\gamma$ agonists and a structurally unrelated PPAR $\gamma$ agonist. Toxicol. Pathol. 2004, 32, 58-63. [CrossRef] [PubMed]

68. Yang, K.; Fan, K.H.; Lamprecht, S.A.; Edelmann, W.; Kopelovich, L.; Kucherlapati, R.; Lipkin, M. Peroxisome proliferator-activated receptor $\gamma$ agonist troglitazone induces colon tumors in normal C57BL/6J mice and enhances colonic carcinogenesis in Apc1638 N/+ Mih1+/- double mutant mice. Int. J. Cancer 2005, 116, 495-499. [CrossRef]

69. Lubet, R.A.; Fischer, S.M.; Steele, V.E.; Juliana, M.M.; Desmond, R.; Grubbs, C.J. Rosiglitazone, a PPAR gamma agonist: Potent promoter of hydroxybutyl(butyl)nitrosamine-induced urinary bladder cancers. Int. J. Cancer 2008, 123, 2254-2259. [CrossRef]

70. Piccinni, C.; Motola, D.; Marchesini, G.; Poluzzi, E. Assessing the association of pioglitazone use and bladder cancer through drug adverse event reporting. Diabetes Care 2011, 34, 1369-1371. [CrossRef] [PubMed] 
71. Sporn, M.B.; Suh, N.; Mangelsdorf, D.J. Prospects for prevention and treatment of cancer with selective PPAR $\gamma$ modulators (SPARMs). Trends Mol. Med. 2001, 7, 395-400. [CrossRef]

72. Koeffler, H.P. Peroxisome proliferator-activated receptor $\gamma$ and cancers. Clin. Cancer Res. 2003, 9, 1-9. [PubMed]

73. Grommes, C.; Landreth, G.E.; Heneka, M.T. Antineoplastic effects of peroxisome proliferator-activated receptor $\gamma$ agonists. Lancet Oncol. 2004, 5, 419-429. [CrossRef]

74. Reddy, J.K.; Azarnoff, D.L.; Hignite, C.E. Hypolipidaemic hepatic peroxisome proliferators form a novel class of chemical carcinogens. Nature 1980, 283, 397-398. [CrossRef] [PubMed]

75. Pozzi, A.; Ibanez, M.R.; Gatica, A.E.; Yang, S.; Wei, S.; Mei, S.; Falck, J.R.; Capdevila, J.H. Peroxisomal proliferator-activated receptor- $\alpha$-dependent inhibition of endothelial cell proliferation and tumorigenesis. J. Biol. Chem. 2007, 282, 17685-17695. [CrossRef] [PubMed]

76. Panigrahy, D.; Kaipainen, A.; Huang, S.; Butterfield, C.E.; Barnés, C.M.; Fannon, M.; Laforme, A.M.; Chaponis, D.M.; Folkman, J.; Kieran, M.W. PPAR $\alpha$ agonist fenofibrate suppresses tumor growth through direct and indirect angiogenesis inhibition. Proc. Natl. Acad. Sci. USA 2008, 105, 985-990. [CrossRef] [PubMed]

77. Zaveri, N.T.; Sato, B.G.; Jiang, F.; Calaoagan, J.; Laderoute, K.R.; Murphy, B.J. A novel peroxisome proliferator-activated receptor $\delta$ antagonist, SR13904, has anti-proliferative activity in human cancer cells. Cancer Biol. Ther. 2009, 8, 1252-1261. [CrossRef]

78. Palkar, P.S.; Borland, M.G.; Naruhn, S.; Ferry, C.H.; Lee, C.; Sk, U.H.; Sharma, A.K.; Amin, S.; Murray, I.A.; Anderson, C.R.; Perdew, G.H.; Gonzalez, F.J.; Müller, R.; Peters, J.M. Cellular and pharmacological selectivity of the peroxisome proliferator-activated receptor- $\beta / \delta$ antagonist GSK3787. Mol. Pharmacol. 2010, 78, 419-430. [CrossRef]

79. Han, L.; Shen, W.J.; Bittner, S.; Kraemer, F.B.; Azhar, S. PPARs: regulators of metabolism and as therapeutic targets in cardiovascular disease. Part I: PPAR- $\alpha$. Future Cardiol. 2017, 13, 259-278. [CrossRef]

80. Kvandová, M.; Majzúnová, M.; Dovinová, I. The role of PPAR $\gamma$ in cardiovascular diseases. Physiol. Res. 2016, 65, S343-S363. [PubMed]

81. Chen, Y.C.; Wu, J.S.; Tsai, H.D.; Huang, C.Y.; Chen, J.J.; Sun, G.Y.; Lin, T.N. Peroxisome proliferator-activated receptor gamma (PPAR- $\gamma$ ) and neurodegenerative disorders. Mol. Neurobiol. 2012, 46, 114-124. [CrossRef]

82. Zhang, S.; Gu, H.; Hu, N. Role of Peroxisome Proliferator-Activated Receptor $\gamma$ in Ocular Diseases. J. Ophthalmol. 2015, 2015, 275435. [CrossRef]

83. Iwashita, A.; Muramatsu, Y.; Yamazaki, T.; Muramoto, M.; Kita, Y.; Yamazaki, S.; Mihara, K.; Moriguchi, A.; Matsuoka, N. Neuroprotective efficacy of the peroxisome proliferator-activated receptor $\delta$-selective agonists in vitro and in vivo. J. Pharmacol. Exp. Ther. 2007, 320, 1087-1096. [CrossRef] [PubMed]

84. Schmuth, M.; Jiang, Y.J.; Dubrac, S.; Elias, P.M.; Feingold, K.R. Thematic review series: Skin lipids. Peroxisome proliferator-activated receptors and liver $\mathrm{X}$ receptors in epidermal biology. J. Lipid Res. 2008, 49, 499-509. [CrossRef]

85. Madrazo, J.A.; Kelly, D.P. The PPAR trio: Regulators of myocardial energy metabolism in health and disease. J. Mol. Cell. Cardiol. 2008, 44, 968-975. [CrossRef] [PubMed]

86. Peters, J.M.; Hollingshead, H.E.; Gonzalez, F.J. Role of peroxisome-proliferator-activated receptor $\beta / \delta$ $(\operatorname{PPAR} \beta / \delta)$ in gastrointestinal tract function and disease. Clin. Sci. (Lond.) 2008, 115, 107-127. [CrossRef] [PubMed]

87. Hong, F.; Xu, P.; Zhai, Y. The Opportunities and Challenges of Peroxisome Proliferator-Activated Receptors Ligands in Clinical Drug Discovery and Development. Int. J. Mol. Sci. 2018, 19, 2189. [CrossRef] [PubMed]

(C) 2019 by the author. Licensee MDPI, Basel, Switzerland. This article is an open access article distributed under the terms and conditions of the Creative Commons Attribution (CC BY) license (http://creativecommons.org/licenses/by/4.0/). 